\title{
Reactions of Donor-Acceptor Cyclopropanes with Naphtho- quinones: Redox and Lewis Acid Catalysis Working in Concert
}

\author{
Alexander Lücht, Lukas J. Patalag, André U. Augustin, Peter G. Jones, and Daniel B. Werz*
}

\begin{abstract}
Reactions of 2-aryl cyclopropane dicarboxylates with naphthoquinones are reported. The key feature was the use of catalytic amounts of $\mathrm{SnCl}_{2}$, which acts as both electron donor and Lewis acid. By an in-situ umpolung of naphthoquinone the formerly electrophilic species is converted into a nucleophile that is able to trigger the ring-opening of the three-membered ring with formation of a new $C-C$ bond. Treatment of these products with base under oxidative conditions resulted - by losing methyl formate - in cyclopentannulated products with fully conjugated $\pi$ systems exhibiting intensive absorptions in the visible range.
\end{abstract}

During recent years donor-acceptor (D-A) cyclopropanes have become one of the most prominent building blocks for threecarbon-atom entities. The high ring strain of cyclopropane, in combination with the polarization of one bond by adjacent donor and acceptor moieties, allows a variety of transformations. ${ }^{[1]}$ Ringenlargement reactions led to five-membered rings by incorporating the acceptor group into the newly formed ring system. ${ }^{[2,3]}[3+n]$-Cycloaddition reactions ${ }^{[4]}$ allowed access to four-, ${ }^{[5]}$ five-, ${ }^{[6]}$ six- $^{[7]}$ and seven-membered ${ }^{[8]}$ carbo- and heterocyclic systems by inserting dipolar or easily polarizable two-, three- or four-atom moieties into the three-membered ring. A third class of reactions employs nucleophiles that open the strained ring system, leading to an acyclic compound with the nucleophile being located adjacent to the donor. Prominent examples have involved phenols,,$^{[9]}$ amines, ${ }^{[10]}$ thiols ${ }^{[11]}$ and azides, ${ }^{[12]}$ but carbon nucleophiles such as indole, ${ }^{[13]}$ silyl enol ethers $^{[14]}$ and naphthol derivatives ${ }^{[15]}$ have also been employed (Scheme 1). The latter examples demonstrate that only very electron-rich components, viz. substrates with high-lying HOMOs, are able to act as suitable nucleophiles for the 1,3-ring-opening reaction. In contrast, electron-poor coupling partners are not able to undergo such a transformation. To provide an example, the reaction with electron-rich naphthol proceeds smoothly, whereas no conversion is observed with electron-poor naphthoquinone.

Our idea was to convert naphthoquinone into a nucleophilic species by generating its anion or dianion in situ. The HOMOs of

${ }^{\star}{ }^{*} \quad$ M. Sc. A. Lücht, Dipl.-Chem. L. J. Patalag, M. Sc. A. U. Augustin Prof. Dr. D. B. Werz

Technische Universität Braunschweig

Institute of Organic Chemistry

Hagenring 30, 38106 Braunschweig (Germany)

E-mail: d.werz@tu-braunschweig.de

Homepage: http://www.werzlab.de

Prof. Dr. P. G. Jones

Technische Universität Braunschweig

Institute of Inorganic and Analytical Chemistry

Hagenring 30, 38106 Braunschweig (Germany) these species are similar in shape and energy to the LUMO of naphthoquinone. Since the largest orbital coefficients of the $\mathrm{HOMO}$ are located at the $\mathrm{C}-\mathrm{C}$ double bond - similar to enol ethers - we expected the compound to undergo C-C bond formation with cleavage of the three-membered ring (Scheme 1).

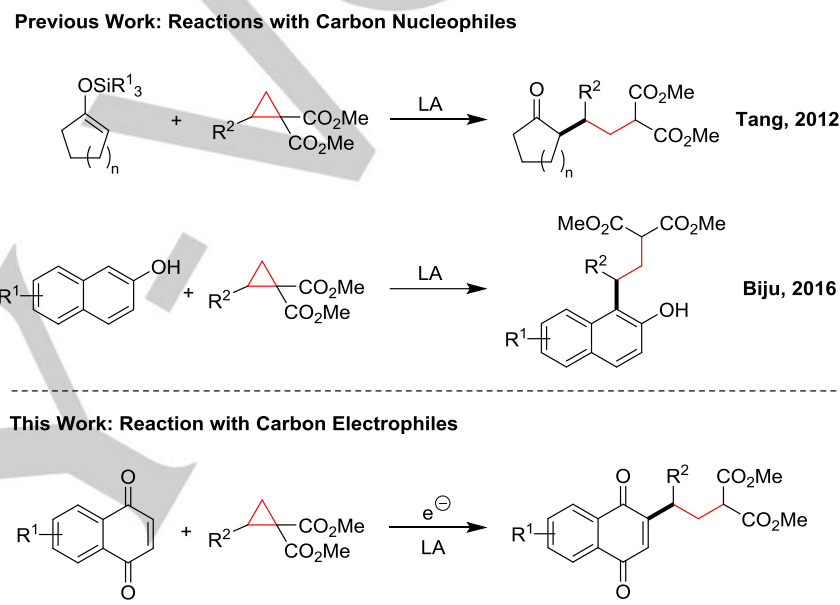

Scheme 1. (top) Reactions of D-A cyclopropanes with carbon nucleophiles. ${ }^{[14,15]}$ (bottom) Reaction of D-A cyclopropanes with carbon electrophiles by a combination of redox and Lewis acid catalysis. LA = Lewis acid.

To test our notion, naphthoquinone (1a) and 2-phenyl cyclopropane dicarboxylate (2a) were chosen as substrates. We immediately found that tin(II) triflate is a suitable reagent to trigger this transformation, yielding desired product $3 \mathbf{a}$ in $31 \%$ (Table 1, entry 1). The tin(II) cation acts as electron donor to convert the naphthoquinone either into its radical anion or dianion. In addition, the $\mathrm{Sn}$ (II) and/or the emerging Sn(IV) system activates the ester groups by acting as a Lewis acid. By changing the counterion of the tin(II) salt to chloride the yield strongly increased to $81 \%$ (entry 2). A screening of the solvent revealed that only chlorinated solvents lead to the desired product (entries 3-5). Decreasing the amount of the electron donor to catalytic amounts even increased the yield to $88 \%$; however, longer reaction times were necessary (entries 6-8). The use of other Lewis acids with reducing character such as $\mathrm{FeCl}_{2}$ and $\mathrm{CuCl}$ proved to be unsuccessful (entries 9-10). The product was not formed in the presence of Lewis acids that are only able to activate the cyclopropane (entries 11-12). 
Table 1. Optimization of the reaction conditions. ${ }^{[a]}$

\begin{tabular}{|c|c|c|c|c|c|}
\hline \multirow[b]{2}{*}{ Entry } & $+{ }_{\mathrm{Ph}} \bigwedge_{2 \mathrm{a}}$ & \multicolumn{2}{|c|}{ LA (x mol\%) } & \multirow[b]{2}{*}{$\mathrm{t}[\mathrm{h}]$} & \multirow[b]{2}{*}{ Yield [\%] } \\
\hline & LA & \multicolumn{2}{|c|}{ solvent, $t$} & & \\
\hline 1 & $\mathrm{Sn}(\mathrm{OTf})_{2}$ & 50 & DCE & 4 & 31 \\
\hline 2 & $\mathrm{SnCl}_{2}$ & 50 & DCE & 2 & 81 \\
\hline 3 & $\mathrm{SnCl}_{2}$ & 50 & $\mathrm{CH}_{2} \mathrm{Cl}_{2}$ & 4 & 70 \\
\hline 4 & $\mathrm{SnCl}_{2}$ & 50 & THF & 4 & - \\
\hline 5 & $\mathrm{SnCl}_{2}$ & 50 & toluene & 4 & - \\
\hline 6 & $\mathrm{SnCl}_{2}$ & 40 & DCE & 2 & 86 \\
\hline 7 & $\mathrm{SnCl}_{2}$ & 20 & DCE & 4 & 88 \\
\hline 8 & $\mathrm{SnCl}_{2}$ & 10 & DCE & 24 & 62 \\
\hline 9 & $\mathrm{FeCl}_{2}$ & 50 & DCE & 4 & - \\
\hline 10 & $\mathrm{CuCl}$ & 50 & DCE & 4 & - \\
\hline 11 & $\mathrm{AlCl}_{3}$ & 50 & $\mathrm{CH}_{2} \mathrm{Cl}_{2}$ & 4 & - \\
\hline 12 & $\ln (\mathrm{OTf})_{3}$ & 50 & $\mathrm{CH}_{2} \mathrm{Cl}_{2}$ & 4 & - \\
\hline
\end{tabular}

$40{ }^{\circ} \mathrm{C}$ under $\mathrm{Ar}$; yields represent isolated products. DCE $=1,2$-Dichloroethane.

With the optimized reaction conditions in hand, we examined the scope for different D-A cyclopropanes (Scheme 2). Transformations proceeded smoothly with halogen-substituted phenyl donors and furnished the desired products in yields up to $85 \%$ (3ab-3ad). Substitution with electron-donating and electronwithdrawing groups in $p$-position is well tolerated and afforded the desired product in moderate to good yields (3ae-3ag).
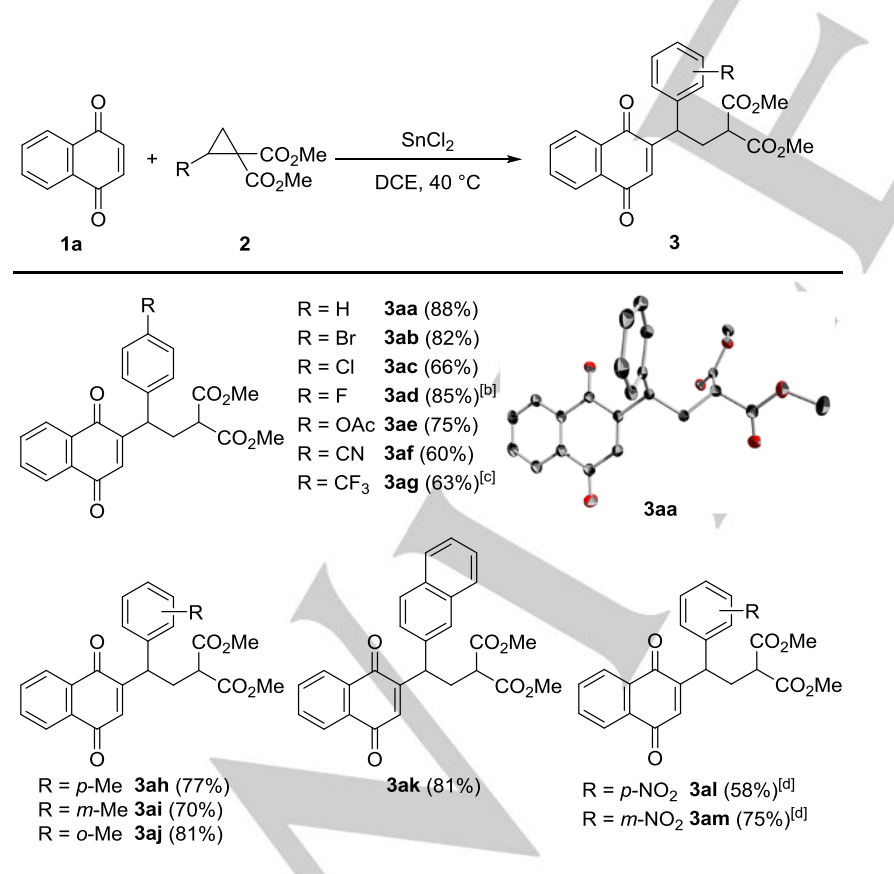

Scheme 2. Scope of the $\mathrm{SnCl}_{2}$-catalyzed reaction with respect to different $\mathrm{D}-\mathrm{A}$ cyclopropanes. ${ }^{[a]}$ General reaction conditions: 1a $(110 \mu \mathrm{mol}), 2(100 \mu \mathrm{mol})$, $\mathrm{SnCl}_{2}(20 \mathrm{~mol} \%), \mathrm{DCE}(1 \mathrm{~mL}), 40^{\circ} \mathrm{C}, 4 \mathrm{~h}$; yields represent isolated products. ${ }^{[b]} 16$ h. ${ }^{[c]} \mathrm{SnCl}_{2}(40 \mathrm{~mol} \%), 2$ h. ${ }^{[d]} \mathrm{SnCl}_{2}(40 \mathrm{~mol} \%), 24 \mathrm{~h}$.
Methyl substitution at $o-, m$-, and $p$-position of the phenyl residue, and also the more bulky naphthyl moiety, allowed a smooth transformation and yields of $77-81 \%$ were obtained (3ah-3ak). It is noteworthy that the reaction time with nitro substituents at the arene unit is longer because of the lower polarization of the bond between the donor and the acceptor moiety in the cyclopropane (58-75\%, 3al-3am).

The method was readily extended to substituted 1,4-naphthoquinones (Scheme 3). Residues in 6-position form two regioisomers in a ratio up to $10: 1$ in yields of $61-76 \%$ (3ba-3da). More electron-rich 1,4-naphthoquinone with two methoxy residues was also able to trigger the ring-opening in $79 \%$ yield (3ea). The use of menadione, 2-methyl-1,4-naphthoquinone, afforded the product in $74 \%$ yield ( 3 fa).

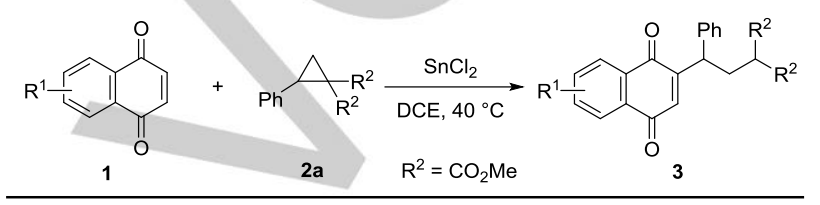<smiles>[R]C([R])CC(CC([R])[R])C1=C(C)C(=O)c2ccccc2C1=O</smiles>

3ea $(79 \%)$

3 fa $(74 \%)$

$\mathrm{R}^{1}=\mathrm{Br} \quad 3 \mathbf{c a}(61 \%, 2: 1)^{[\mathrm{b}]}$

$\mathrm{R}^{1}=\mathrm{NO}_{2} \quad 3 \mathrm{da}(64 \%, 1.8: 1)^{[\mathrm{b}]}$

Scheme 3. Scope of the $\mathrm{SnCl}_{2}$-catalyzed reaction with respect to different naphthoquinones. ${ }^{[a]}$ General reaction conditions: $1(110 \mu \mathrm{mol}), \mathbf{2 a}(100 \mu \mathrm{mol})$, $\mathrm{SnCl}_{2}(20 \mathrm{~mol} \%)$, DCE $(1 \mathrm{~mL}), 40^{\circ} \mathrm{C}, 4 \mathrm{~h}$; yields represent isolated products. ${ }^{[b]} \mathrm{SnCl}_{2}$ (40 mol\%), $2 \mathrm{~h}$; regioisomeric mixtures are obtained.

After having established a method for this unprecedented C-C bond-forming reaction between an electrophile and the electrophilic carbon of a D-A cyclopropane, we asked ourselves whether a cyclopentannulation process might be also feasible. Indeed, when an amine as base was added to the mixture, the reaction afforded an intensively colored red dye. This color led us to conclude that not only a five-membered ring under Michael conditions has been formed, but a larger $\pi$ system has been generated (Scheme 4). Careful spectroscopic analyses and X-ray crystallography revealed that compounds of type $\mathbf{4}$ were obtained. Further optimization studies showed that DBN was the base of choice for this transformation and the use of $\mathrm{MnO}_{2}$ as oxidant increased the yield of $\mathbf{4}$. The basic and oxidative conditions resulted in the loss of one ester moiety and generation of an extended $\pi$ system. ${ }^{[16]}$ Some of the systems that we had already investigated in the initial step were subjected to this one-pot process (Scheme 4). The parent compound was obtained in $71 \%$ yield (4aa). A variety of D-A cyclopropanes with halogens (4ab4ad), but also strongly electron-withdrawing (e.g. $\mathrm{CF}_{3}, \mathrm{NO}_{2}$ ) or electron-donating groups at the phenyl unit underwent a smooth cyclopentannulation in overall yields of $59-71 \%$. Even more steric bulk at the donor terminus of the cyclopropane was not detrimental to the transformation (4aj, 4ak). 

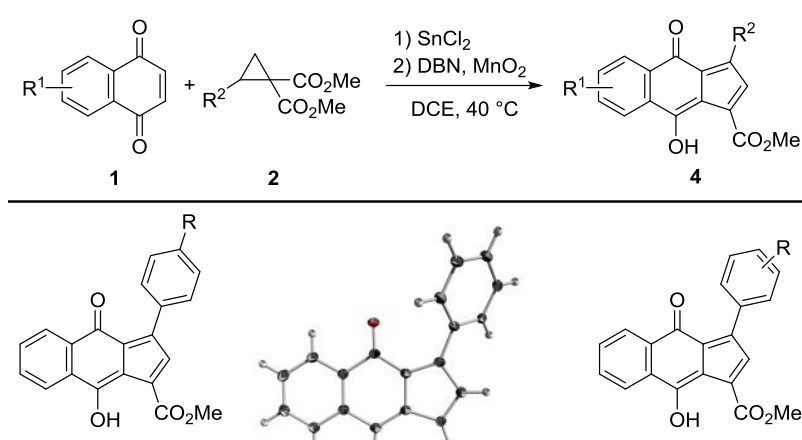

$\mathrm{R}=\mathrm{H} \quad$ 4aa $(71 \%)^{[\mathrm{cc}]}$

$\mathrm{R}=\mathrm{Br} \quad$ 4ab (59\%)

$\mathrm{R}=\mathrm{Cl} \quad$ 4ac $(65 \%)$

$\mathrm{R}=\mathrm{F} \quad$ 4ad $(71 \%)$

$\mathrm{R}=\mathrm{CF}_{3} \quad \mathbf{4 a g}(63 \%)^{[\mathrm{b}]}$
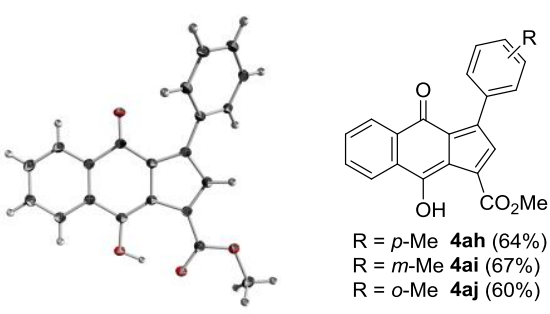

$\mathrm{R}=p-\mathrm{Me}$ 4ah $(64 \%)$

$\mathrm{R}=m$-Me 4ai $(67 \%)$

$\mathrm{R}=o-\mathrm{Me} \mathrm{4aj}(60 \%)$

4aa
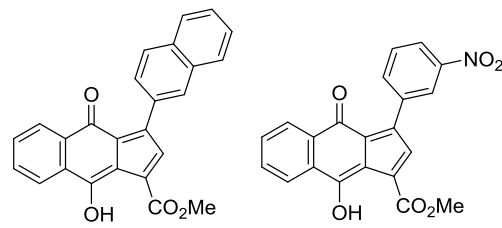

4ak $(70 \%)$

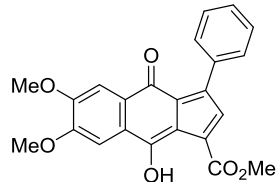

4ea $(57 \%)$

Scheme 4. Scope of the one-pot [3+2]-cyclopentannulation to a fully conjugated $\pi$ system. ${ }^{[a] G e n e r a l ~ r e a c t i o n ~ c o n d i t i o n s: ~} 1(110 \mu \mathrm{mol}), 2(100 \mu \mathrm{mol}), \mathrm{SnCl}_{2}$ (20 mol\%), DCE (1 mL), $40{ }^{\circ} \mathrm{C}, 4-16 \mathrm{~h} ; \mathrm{MnO}_{2}(600 \mu \mathrm{mol})$ and DBN $(500 \mu \mathrm{mol})$, $40{ }^{\circ} \mathrm{C}, 2 \mathrm{~h}$; yields represent isolated products. ${ }^{[\mathrm{b}]} \mathrm{SnCl}_{2}$ (40 mol\%), $2-24 \mathrm{~h}$. ${ }^{[c]}$ Reaction carried out in large scale $(2.13 \mathrm{mmol})$ led to a yield of $50 \%$. DBN = 1,5-Diazabicyclo[4.3.0]-non-5-ene.

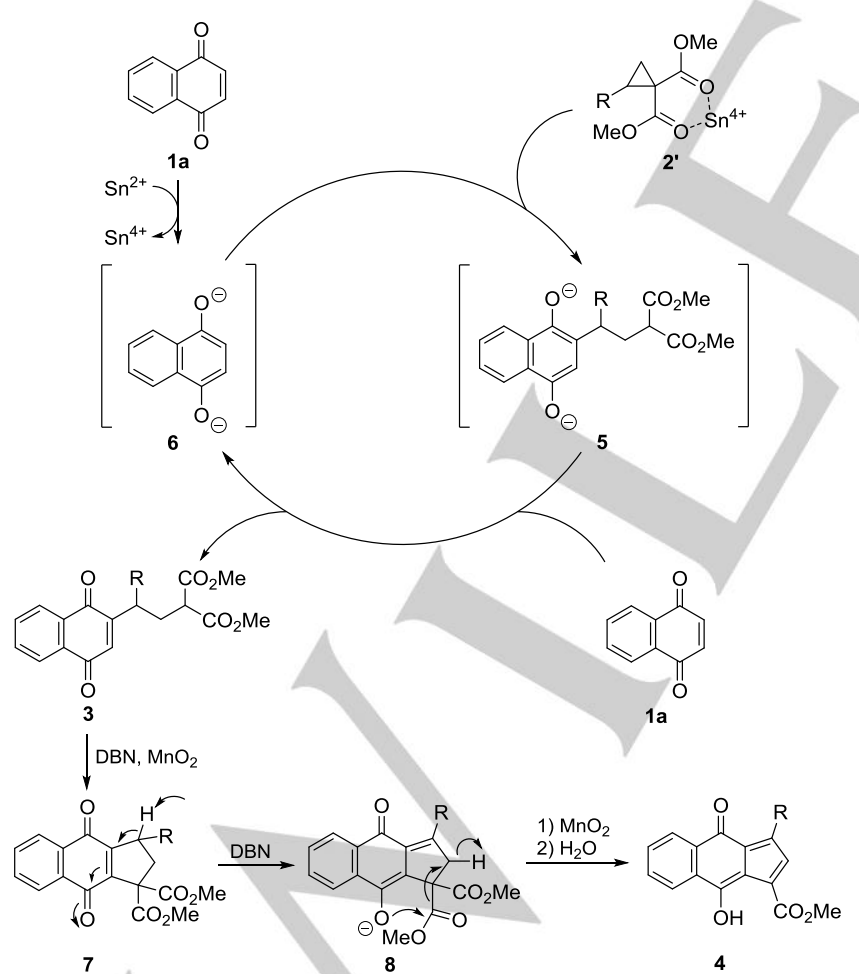

Scheme 5. Proposed mechanism for the ring-opening of the D-A cyclopropane by redox and Lewis acid catalysis including further steps to cyclopentannulated product 4.

Regarding the mechanism of the initial C-C bond formation, we ascribe a dual role to the tin salt (Scheme 5). In a first step Sn(II) initiates the generation of a nucleophilic naphthoquinone dianion 6, while $\mathrm{Sn}(\mathrm{II})$ is oxidized to $\mathrm{Sn}(\mathrm{IV})$. In addition, the $\mathrm{Sn}(\mathrm{IV})$ species activates the D-A cyclopropane by chelating the two carboxylates ${ }^{[17,18]}$ and thus facilitates a ring-opening by the nucleophilic dianion that is generated in situ. The additional alkyl substituent of the dianion 5 increases the reduction potential by raising the $\mathrm{HOMO}$ and allows the conversion of naphthoquinone 1a into its dianion while naphthoquinone derivative $\mathbf{3}$ is obtained. ${ }^{[19]}$ In the presence of DBN as base, a Michael addition of the malonate moiety to the electron-poor double bond takes place; oxidative conditions lead to the cyclopentannulated naphthoquinone 7 . The presence of this intermediate was proven by X-ray crystallography (see Supporting Information). ${ }^{[20,21]} \mathrm{DBN}$ mediated deprotonation at the benzylic position leads to enolate $\mathbf{8}$, which cleaves one of the ester groups. Oxidative conditions afforded fully conjugated 4.

This push-pull system resembles the scaffold found in oxonol dyes; however, the polymethine chain is uniquely integrated into a fused fulvene-type motif, which provides a basis for conversion into corresponding restricted cyanine frameworks. To demonstrate the synthetic value of this cyclopentannulation process, we investigated follow-up chemistry using $\mathbf{4 a}$ as substrate. The hydroxy group was easily converted into triflate $\mathbf{9}$, which proved to be an ideal intermediate for a variety of further transformations (Scheme 6). Reaction with secondary aliphatic and aromatic amines furnished $\mathbf{1 0}$ and $\mathbf{1 1}$ whereas tetrabutylammonium bromide provided 12. Triflate 9 also engaged in a Pd-catalyzed Sonogashira-type reaction yielding alkyne $\mathbf{1 3}$.

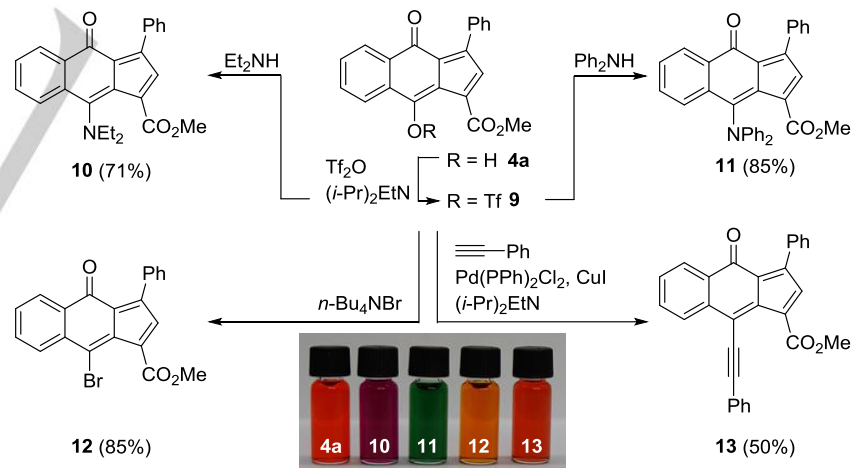

Scheme 6. Follow-up chemistry. Yields are over two steps including triflation.

In conclusion, we report an unprecedented strategy to force D-A cyclopropanes to react with naphthoquinones by a combination of redox and Lewis acid catalysis. Key to success was the conversion of the electrophilic naphthoquinone into a nucleophilic species by using $\mathrm{SnCl}_{2}$. As products, 2-functionalized naphthoquinone derivatives were obtained in yields up to $88 \%$. The emerging products were further transformed in one step under basic and oxidative conditions to intensely colored cyclopentannulated products consisting of a fully conjugated $\pi$ system. 


\section{Acknowledgments}

This research was supported by the European Research Council (ERC Consolidator Grant "GAINBYSTRAIN" to D.B.W.). We are grateful to our reviewers for highly useful comments.

Keywords: cyclopropane $\cdot$ donor-acceptor systems • tin • naphthoquinone $\cdot$ annulation

[1] General overview of donor-acceptor cyclopropanes: a) H.-U. Reissig, R Zimmer, Chem. Rev. 2003, 103, 1151; b) M. Yu, B. L. Pagenkopf Tetrahedron 2005, 61, 321; c) D. Agrawal, V. K. Yadav, Chem. Commun. 2008, 6471; d) C. A. Carson, M. A. Kerr, Chem. Soc. Rev. 2009, 38 3051; e) F. De Simone, J. Waser, Synthesis 2009, 3353; f) M. A. Cavitt, L. H. Phun, S. France, Chem. Soc. Rev. 2014, 43, 804; g) T. F. Schneider J. Kaschel, D. B. Werz, Angew. Chem. Int. Ed. 2014, 53, 5504; Angew. Chem. 2014, 126, 5608; h) R. A. Novikov, Y. V. Tomilov, Mendeleev Commun. 2015, 25, 1; i) H. K. Grover, M. R. Emmett, M. A. Kerr, Org. Biomol. Chem. 2015, 13, 655; j) V. A. Rassadin, Y. Six, Tetrahedron 2016, 72, 4701; j) N. R. O'Connor, J. L. Wood, B. M. Stoltz, Isr. J. Chem. 2016, 56, 431

[2] a) H.-U. Reissig, E. Hirsch, Angew. Chem. Int. Ed. Engl. 1980, 19, 813 Angew. Chem. 1980, 92, 839; b) C. Brückner, H.-U. Reissig, Angew. Chem. Int. Ed. Engl. 1985, 24, 588; Angew. Chem. 1985, 97, 578.

[3] a) C. Brand, G. Rauch, M. Zanoni, B. Dittrich, D. B. Werz, J. Org. Chem. 2009, 74, 8779; b) T. F. Schneider, J. Kaschel, B. Dittrich, D. B. Werz Org. Lett. 2009, 11, 2317; c) S. J. Gharpure, M. K. Shukla, U. Vijayasree Org. Lett. 2009, 11, 5466; d) T. F. Schneider, J. Kaschel, S. I. Awan, B. Dittrich, D. B. Werz, Chem. Eur. J. 2010, 16, 11276; e) J. Kaschel, T. F. Schneider, D. Kratzert, D. Stalke, D. B. Werz, Angew. Chem. Int. Ed. 2012, 51, 11153; Angew. Chem. 2012, 124, 11315; f) C. D. Schmidt, J. Kaschel, T. F. Schneider, D. Kratzert, D. Stalke, D. B. Werz, Org. Lett. 2013, 15, 6098; g) J. Kaschel, C. D. Schmidt, M. Mumby, D. Kratzert, D. Stalke, D. B. Werz, Chem. Commun. 2013, 49, 4403.

[4] R. A. Novikov, A. V. Tarasova, V. A. Korolev, V. P. Timofeev, Y. V. Tomilov, Angew. Chem. Int. Ed. 2014, 53, 3187; Angew. Chem. 2014, 126, 3251.

[5] a) A. Ghosh, S. Mandal, P. K. Chattaraj, P. Banerjee, Org. Lett. 2016, 18 4940; b) J.-Q. Han, H.-H. Zhang, P.-F. Xu, Y.-C. Luo, Org. Lett. 2016, 18, 5212.

[6] a) P. D. Pohlhaus, S. D. Sanders, A. T. Parsons, W. Li, J. S. Johnson, J. Am. Chem. Soc. 2008, 130, 8642; b) W. Zhu, J. Fang, Y. Liu, J. Ren, Z. Wang, Angew. Chem. Int. Ed. 2013, 52, 2032; Angew. Chem. 2013, 125 2086; c) S. Racine, F. de Nanteuil, E. Serrano, J. Waser, Angew. Chem. Int. Ed. 2014, 53, 8484; Angew. Chem. 2014, 126, 8624; d) S Chakrabarty, I. Chatterjee, B. Wibbeling, C. G. Daniliuc, A. Studer, Angew. Chem. Int. Ed. 2014, 53, 5964; Angew. Chem. 2014, 126, 6074 e) J. Zhu, Y. Liang, L. Wang, Z.-B. Zheng, K. N. Houk, Y. Tang, J. Am. Chem. Soc. 2014, 136, 6900; f) Z. Yuan, W. Wei, A. Lin, H. Yao, Org Lett. 2016, 18, 3370; g) C. Ma, Y. Huang, Y. Zhao, ACS Catal. 2016, 6, 6408; h) J.-A. Xiao, J. Li, P.-J. Xia, Z.-F. Zhou, Z.-X. Deng, H.-Y. Xiang X.-Q. Chen, H. Yang, J. Org. Chem. 2016, 81, 11185; i) J. E. Curiel Tejeda, L. C. Irwin, M. A. Kerr, Org. Lett. 2016, 18, 4738; j) S. Racine, B. Hegedus, R. Scopelliti, J. Waser, Chem. Eur. J. 2016, 22, 11997; k) R. K. Varshnaya, P. Banerjee, Eur. J. Org. Chem. 2016, 4059; I) J. Sabbatani, N. Maulide, Angew. Chem. Int. Ed. 2016, 55, 6780; Angew. Chem. 2016, 128, 6892; m) D. D. Borisov, R. A. Novikov, Y. V. Tomilov,
Angew. Chem. Int. Ed. 2016, 55, 12233; Angew. Chem. 2016, 128, 12421; n) D.-C. Wang, M.-S. Xie, H.-M. Guo, G.-R. Qu, M.-C. Zhang S.-L. You, Angew. Chem. Int. Ed. 2016, 55, 14111; Angew. Chem. 2016, 128, 14317; o) R. Dey, P. Banerjee, Org. Lett. 2017, 19, 304.

[7] a) R. A. Novikov, A. V. Tarasova, V. A. Korolev, E. V. Shulishov, V. P. Timofeev, Y. V. Tomilov, J. Org. Chem. 2015, 80, 8225; b) L. K. B. Garve M. Petzold, P. G. Jones, D. B. Werz, Org. Lett. 2016, 18, 564; c) T. Chidley, N. Vemula, C. A. Carson, M. A. Kerr, B. L. Pagenkopf, Org. Lett 2016, 18, 2922; d) S. Das, S. Chakrabarty, C. G. Daniliuc, A. Studer, Org. Lett. 2016, 18, 2784; e) R. A. Novikov, A. V. Tarasova, D. A Denisov, D. D. Borisov, V. A. Korolev, V. P. Timofeev, Y. V. Tomilov, J. Org. Chem. 2017, 82, 2724; f) K. Mondal, S. C. Pan, Eur. J. Org. Chem. 2017, 534; g) Y.-C. Luo, H. Ma, X.-Q. Hu, P.-F. Xu, J. Org. Chem. 2017, $82,1013$.

[8] a) O. A. Ivanova, E. M: Budynina, Y. K. Grishin, I. V. Trushkov, P. V. Verteletskii, Angew. Chem. Int. Ed. 2008, 47, 1107; Angew. Chem. 2008 120, 1123; b) H. Xu, J.-L. Hu, L. Wang, S. Liao, Y. Tang, J. Am. Chem. Soc. 2015, 137, 8006; c) L. K. B. Garve, M. Pawliczek, J. Wallbaum, P. G. Jones, D. B. Werz, Chem. Eur. J. 2016, 22, 521; d) C. Zhang, J. Tian, J. Ren, Z. Wang, Chem. Eur. J. 2017, 23, 1231.

[9] O. Lifchits, D. Alberico, I. Zakharian, A. B. Charette, J. Org. Chem. 2008 73,6838 .

[10] a) L. A. Blanchard, J. A. Schneider, J. Org. Chem. 1986, 51, 1372; b) O. Lifchits, A. B. Charette, Org. Lett. 2008, 10, 2809; c) Y.-Y. Zhou, L.-J. Wang, J. Li, X.-L. Sun, Y. Tang, J. Am. Chem. Soc. 2012, 134, 9066.

[11] a) C. M. Braun, A. M. Shema, C. C. Dulin, K. A. Nolin, Tetrahedron Lett 2013, 54, 5889; b) H.-P. Wang, H.-H. Zhang, X.-Q. Hu, P.-F. Xu, Y.-C Luo, Eur. J. Org. Chem. 2015, 2015, 3486.

[12] a) M. R. Emmett, H. K. Grover, M. A. Kerr, J. Org. Chem. 2012, 77, 6634 b) K. L. Ivanov, E. V. Villemson, E. M. Budynina, O. A. Ivanova, I. V. Trushkov, M. Y. Melnikov, Chem. Eur. J. 2015, 21, 4975.

[13] a) S. M. Wales, M. M. Walker, J. S. Johnson, Org. Lett. 2013, 15, 2558; b) F. de Nanteuil, J. Loup, J. Waser, Org. Lett. 2013, 15, 3738.

[14] a) J.-P. Qu, Y. Liang, H. Xu, X.-L. Sun, Z.-X. Yu, Y. Tang, Chem. Eur. J. 2012, 18, 2196; b) H. Xu, J.-P. Qu, S. Liao, H. Xiong, Y. Tang, Angew. Chem. Int. Ed. 2013, 52, 4004; Angew. Chem. 2013, 125, 4096.

[15] T. Kaicharla, T. Roy, M. Thangaraj, R. G. Gonnade, A. T. Biju, Angew. Chem. Int. Ed. 2016, 55, 10061; Angew. Chem. 2016, 128, 10215.

[16] Such a scaffold without any substituents was once created by a ringcontraction reaction: J. Griffiths, M. Lockwood, Tetrahedron Lett. 1975, $16,683$.

[17] R. A. Novikov, D. O. Balakirev, V. P. Timofeev, Y. V. Tomilov, Organometallics 2012, 31, 8627.

[18] $\mathrm{Sn}(\mathrm{IV})$ acts as Lewis acid catalyst, but not $\mathrm{Sn}(\mathrm{II})$. In a separate experiment naphthoquinone dianion 6 was generated by deprotonation of naphthalene-1,4-diol with $\mathrm{NaH}$. In the case of added $\mathrm{SnCl}_{4}$ the desired product was observed while with $\mathrm{SnCl}_{2}$ no reaction took place (for details see Supporting Information).

[19] The possibility that also the semiquinone radical anion being present in equilibrium with naphthoquinone and its dianion acts as nucleophile cannot be completely excluded.

[20] a) CrysAlisPro; Agilent Technologies: Oxford, U.K., 2013; b) G. M Sheldrick, SHELXL-97, University of Göttingen, Germany, 1997; c) G. M. Sheldrick, Acta Crystallogr., Sect. A 2008, 64, 112-122.

[21] The CIF files have been deposited with the Cambridge Crystallographic Data Centre as supplementary publication no. CCDC-1543231 (3aa), -1543232 (4aa) and -1543233 (7). 


\section{COMMUNICATION}

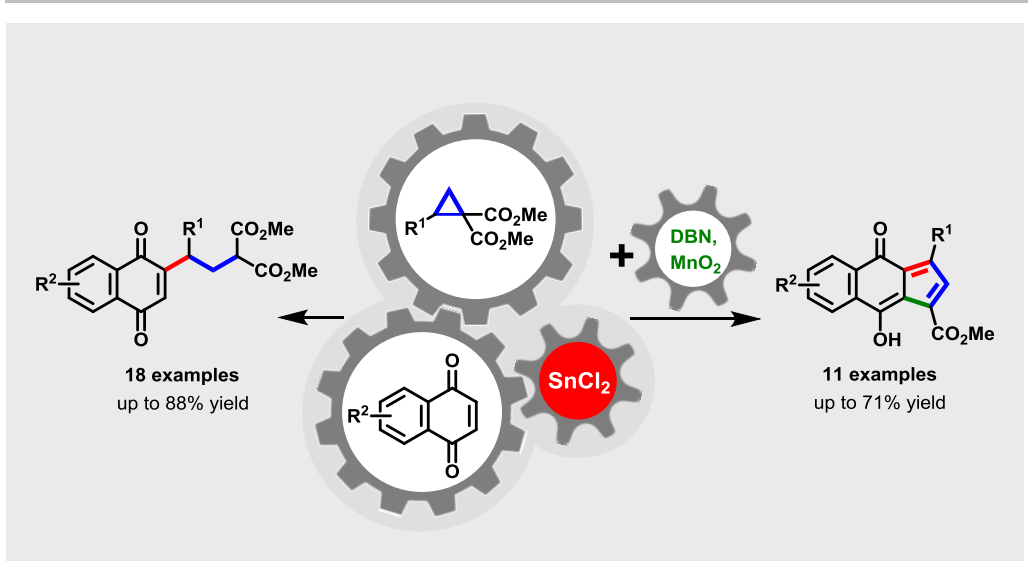

Alexander Lücht, Lukas J. Patalag, André U. Augustin, Peter G. Jones, Daniel B. Werz*

Page No. - Page No.

Reactions of Donor-Acceptor Cyclopropanes: Redox and Lewis Acid Catalysis Working in Concert

Electron power: Electrophilic naphthoquinone is converted by a catalytic amount of tin(II) into the respective nucleophilic species which is able to open donor-acceptor cyclopropanes. Basic oxidative conditions lead to a [3+2]-cyclopentannulation resulting in a completely conjugated $\pi$ system. 